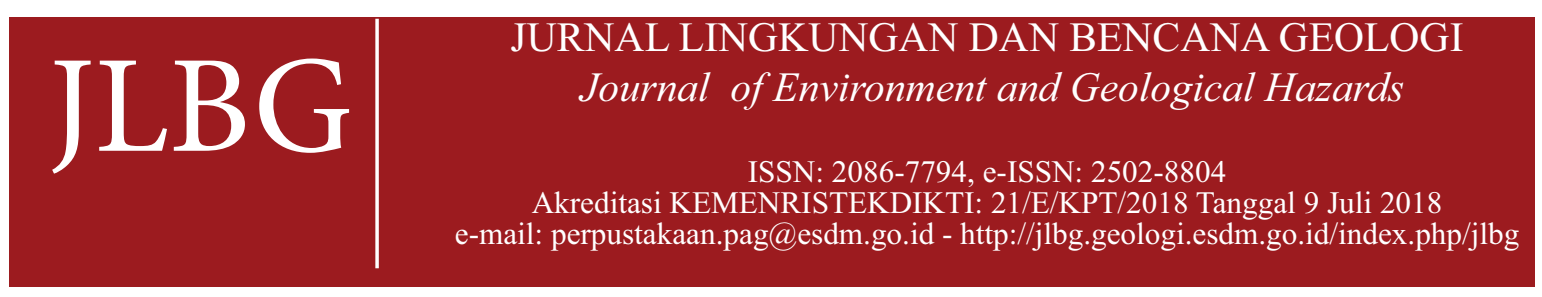

\title{
Rekonstruksi Model Bawah Permukaan Sesar Palu Berdasarkan Hasil Relokasi Hiposenter
}

\section{Subsurface Model Reconstruction of Palu Fault Based on Hypocenter Relocation Results}

\author{
Priyobudi dan Mohamad Ramdhan
}

Badan Meteorologi, Klimatologi, dan Geofisika (BMKG)

Jalan Angkasa I No. 2, Kemayoran, Jakarta Pusat, 10720, Indonesia

e-mail: mohamad.ramdhan@bmkg.go.id /mramdhan123@gmail.com

Naskah diterima 02 November 2019, selesai direvisi 15 April 2020, dan disetujui 29 April 2020

\begin{abstract}
ABSTRAK
Relokasi hiposenter merupakan teknik umum yang digunakan untuk memahami kondisi tektonik di suatu area. Kondisi bawah permukaan sesar Palu-Koro pada segmen Palu-Donggala belum diketahui dengan baik sehingga penelitian ini dimaksudkan untuk merekontruksi area bawah permukaan sepanjang segmen sesar tersebut. Rekontruski sesar aktif pada penelitian ini menggunakan 364 hiposenter dari katalog gempa bumi Badan Meteorologi, Klimatologi dan Geofisika (BMKG) yang sudah terelokasi . Relokasi hiposenter yang digunakan pada penelitian ini mengaplikasikan metode teleseismic double-difference. Sebaran hiposenter hasil relokasi dikluster dengan menggunakan metode heat map sehingga dapat menegaskan pola-pola kelurusan yang digunakan untuk merekonstruksi bidang-bidang sesar. Hasil penelitian ini menunjukkan bahwa sistem Sesar Palu terdiri dari satu sesar utama dan dua sesar sintetik. Sesar utama menempati sisi timur lembah Palu. Sesar ini berupa bidang lurus berarah utara-selatan dari utara Kabupaten Donggala hingga Kota Palu. Gempa bumi dengan magnitudo Mw 7,5 terjadi pada sesar utama ini. Sesar sintetik berupa bidang lengkung berarah barat laut-tenggara membentuk sudut terhadap sesar utama. Hasil rekonstruksi juga menunjukkan beberapa flower structure yang umum terjadi dalam sebuah sistem sesar mendatar.
\end{abstract}

Kata kunci: BMKG, hiposenter, Palu, relokasi, sesar

\section{ABSTRACT}

Hypocenter relocation is a common technique for understanding tectonic conditions in an area. The subsurface conditions of the Palu-Koro fault in the Palu-Donggala segment are not well known, so this study is intended to reconstruct subsurface areas along the fault segment. This study uses 364 relocated hypocenter results from the Indonesian Agency for Meteorology, Climatology, dan Geophysics (BMKG). The relocated hypocenter in this study applied the teleseismic double-difference method. Distributions of relocated hypocenter are clustered using the heat map method to emphasize the lineament pattern that is used to reconstruct fault planes. The results show that the Palu fault system consists of the main fault and two synthetic faults. The main fault is in the eastern part of the Palu valley. The fault is a straight plane that extent in the north-south direction from the northern part of Donggala regency to Palu city. The earthquake of Mw 7.5 has occurred on this main fault. The synthetic faults are formed curvature planes that made an angle to the main fault. The study results also show some flower structures that commonly occur in a horizontal fault system.

Keyword: BMKG, hypocenter, Palu, relocation, fault

\section{PENDAHULUAN}

Gempa bumi di wilayah Kota Palu dan sekitarnya pada 28 September 2018 dengan magnitudo $\mathrm{Mw}$ 7,5 merupakan gempa bumi yang menyebabkan kerusakan infrastruktur yang parah dan jumlah korban jiwa yang sangat banyak. Kedua kerugian tersebut diakibatkan oleh guncangan yang sangat kuat, likuefaksi 
dan tsunami akibat longsoran. Gempa bumi ini disebabkan oleh pergeseran yang terjadi pada Sesar Palu-Koro (PK) yang membelah Pulau Sulawesi.

Secara tektonik Sulawesi dibagi menjadi beberapa blok, yaitu: Blok Manado, Blok Sulawesi Utara, Blok Sulawesi Timur dan Blok Makassar. Sesar PK merupakan konsekuensi dari adanya rotasi blok Sulawesi Utara searah jarum jam relatif terhadap Blok Makassar. Rotasi searah jarum jam ini mengakibatkan gerakan mendatar sinistral di sepanjang pertemuan kedua blok tersebut yaitu sesar Palu-Koro-Matano (Socquet drr., 2006). Sejumlah penelitian menyebutkan bahwa Sesar PK merupakan bidang sesar sederhana dan lurus sehingga memungkinkan terjadinya supershear rupture (Bao drr., 2019). Gempa bumi disebut supershear rupture bila kecepatan rupture pada bidang gempa bumi lebih besar dari gelombang permukaan (Fang drr., 2019). Penelitian lain dengan menggunakan metode gravitasi menunjukkan bahwa Sesar PK terdiri dari beberapa pasang bidang sesar (Jamidun drr., 2019). Berdasarkan penginderaan jauh, analisa morfometri dan survei geologi permukaan, di selatan Kota Palu ditemukan beberapa manifestasi keberadaan sesar ini. Manifestasi ini berupa kelurusan morfologi, terganggunya pola pengaliran sungai dan endapan paleoseismik. Pada segmen ini, Sesar Palu terbagi menjadi enam segmen mulai dari Leboni di selatan hingga Kota Palu di utara. Keenam segmen ini merupakan bagian dari Sesar PK di sisi bagian barat Lembah Palu (Bellier drr., 2001; Watkinson dan Hall, 2017). Hamilton (1979) menyatakan bahwa Sesar PK di area Kota Palu dan sekitarnya terdiri dari sepasang bidang sesar yaitu barat dan timur yang membentuk Lembah Palu.

Penelitian ini bertujuan untuk merekonstruksi model bawah permukaan sistem Sesar PK di antara Kota Palu, Donggala hingga selatan Tolitoli terutama untuk segmen yang berada di wilayah lautan. Karena tertutup badan air, metode penginderaan jauh dan morfometri tidak dapat digunakan untuk menelusuri jejak sesar di permukaan. Dalam penelitian ini dilakukan rekonstruksi model bawah permukaan Sesar Palu melalui analisis kelurusan sebaran hiposenter gempa bumi dari hasil relokasi hiposenter katalog gempa bumi BMKG.

Hasil relokasi hiposenter telah diaplikasikan dengan baik untuk memahami kondisi tektonik di sejumlah wilayah di Indonesia (Ramdhan dan Nugraha, 2013; Ismullah drr., 2017; Ramdhan drr., 2017; Nugraha drr., 2018; Ramdhan dan Priyobudi, 2019). Hasil relokasi hiposenter juga bisa digunakan untuk mendeliniasi struktur sesar di bawah permukaan sebagaimana dilakukan di wilayah Wenchuan, Cina (Zhao drr., 2011). Struktur sesar di wilayah tersebut berhasil dideliniasi dari sebaran aftershock gempa yang diakibatkan oleh gempa utama dengan magnitudo sebesar Ms 8,0.

\section{METODE PENELITIAN}

Data penelitian berasal dari katalog gempa bumi BMKG yang sudah terelokasi hiposenternya periode April 2009-Desember 2018 (Ramdhan drr., 2019). Data gempa yang direlokasi hiposenternya berada pada rentang $90^{\circ}-160^{\circ} \mathrm{E}$ dan $15^{\circ} \mathrm{S}-$ $15^{\circ} \mathrm{N}$. Kejadian gempa bumi terelokasi direkam tidak hanya oleh jaringan seismik BMKG tetapi juga oleh jaringan seismik internasional. Jaringan seismik BMKG yang digunakan sebanyak 174 dan jaringan seismik internasional sebanyak 146. Relokasi hiposenter yang digunakan pada penelitian ini menggunakan metode teleseismic double-difference (teletomoDD) (Pesicek drr., 2010) dengan model kecepatan 3-D regional di Indonesia (Widiyantoro dan van der Hilst, 1996, 1997) dan model kecepatan 1-D global (Kennett drr., 1995). Ukuran grid horisontal yang digunakan sebesar $1^{0} \mathrm{x} 1^{0}$. Semua parameter tersebut mengacu pada penelitian sebelumnya yang merelokasi parameter hiposenter katalog BMKG di area Sunda Arc (Nugraha drr., 2018). Rentang waktu residual untuk gelombang $\mathrm{P}$ antara -3 detik sampai 3 detik dan untuk gelombang S sebesar -5 detik sampai 5 detik. Rentang 
waktu residual untuk gelombang S lebih besar dari rentang waktu residual gelombang P karena onset gelombang $\mathrm{S}$ tidak sejelas gelombang $\mathrm{P}$. Hal ini disebabkan oleh signal to noise ratio (SNR) gelombang $\mathrm{S}$ lebih rendah daripada gelombang P.

Data gempa yang digunakan pada penelitian ini berada pada rentang koordinat $119,0^{\circ}-120,0^{\circ} \mathrm{E}$ dan $1,0^{\circ} \mathrm{S}-0,5^{\circ} \mathrm{N}$ dengan kriteria setiap gempa bumi paling tidak memiliki enam fase gelombang seismik (baik gelombang $\mathrm{P}$ dan $\mathrm{S}$ atau gelombang P saja). Jumlah minimal fase tersebut dipilih agar perhitungan inversinya over-determined di mana jumlah data observasi lebih besar dari jumlah modelnya yang berupa parameter hiposenter (Grandis, 2009). Data gempa bumi yang digunakan termasuk gempa bumi mainshock Mw 7,5 dan gempa bumi foreshock Mw 6,0 serta gempa bumi aftershock dari gempa bumi $\mathrm{Mw}$ 7,5. Gambar 1 menunjukkan area penelitian pada penelitian ini dengan jaringan seismik di wilayah Sulawesi dan sekitarnya.

\section{HASIL DAN PEMBAHASAN}

Jumlah gempa bumi terelokasi yang digunakan pada area penelitian ini sebanyak 364 event dengan maksimal kedalaman gempa bumi sebesar $20 \mathrm{~km}$. Setelah direlokasi episenter gempa bumi umumnya berpindah ke arah barat laut dengan perpindahan maksimum sejauh $28,4 \mathrm{~km}$ dan perpindahan minimum sebesar $0,24 \mathrm{~km}$ dari posisi sebelumnya. Adapun ratarata perpindahan episenter sebesar $6,3 \mathrm{~km}$ dari posisi sebelumnya. Gambar 2(a) menunjukkan vektor relokasi dari setiap episenter gempa bumi relatif terhadap katalog BMKG. Gambar 2(b) menunjukkan arah umum perpindahan hiposenter ke arah barat laut. Dengan dilakukannya relokasi ini maka hiposenter gempa yang tadinya berada di daratan leher Pulau Sulawesi bergeser lebih mendekati pantai barat. Sebaran episenter sebelum dan sesudah relokasi hiposenter ditunjukkan oleh Gambar 3. Hasil relokasi hiposenter menunjukkan terdapat perubahan kedalaman yang signifikan di

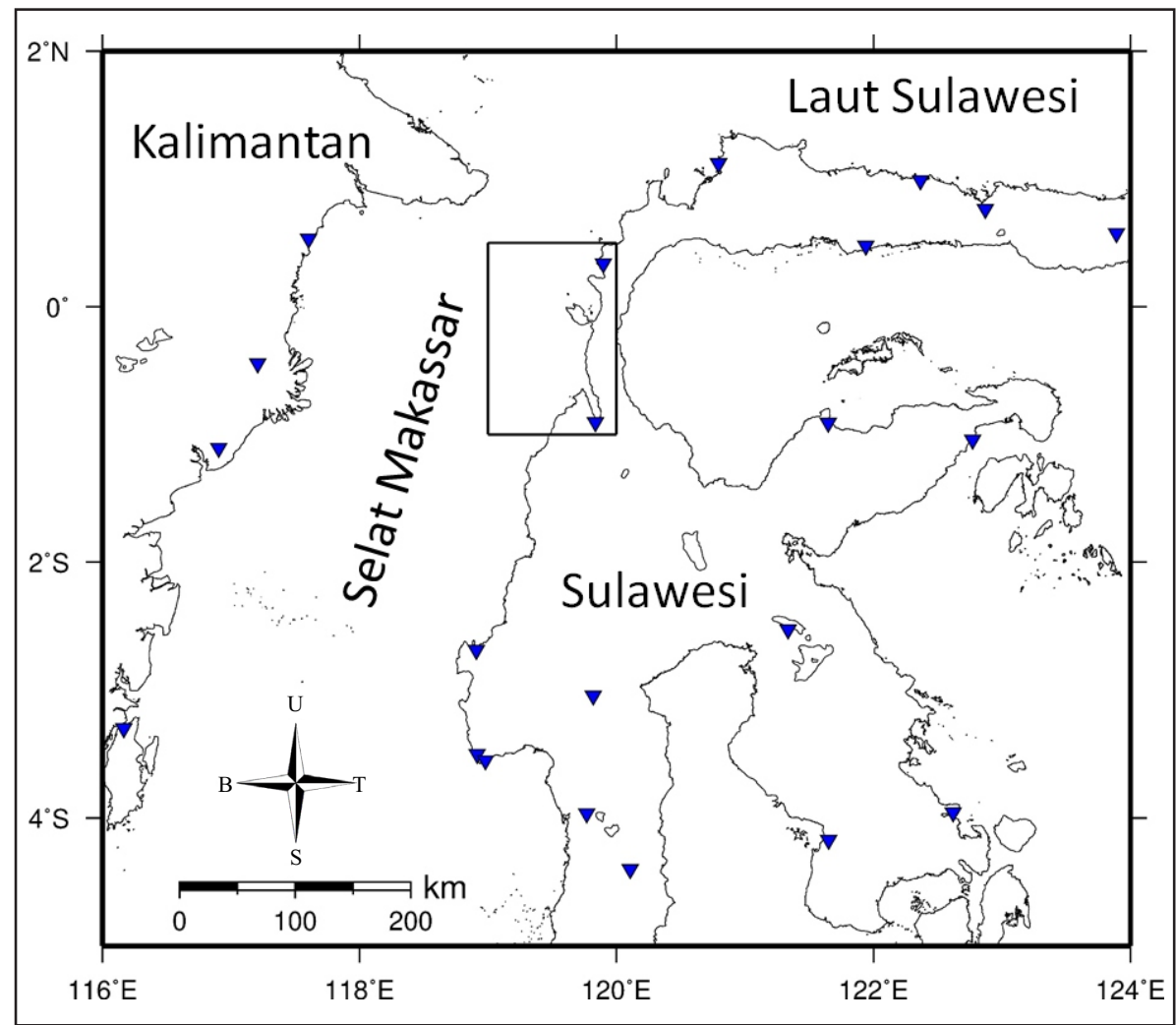

Gambar 1. Sebaran stasiun pencatat gempa bumi (segitiga terbalik biru) di area Pulau Sulawesi dan sekitarnya yang digunakan dalam penelitian ini. Area penelitian berada di area kotak hitam. 


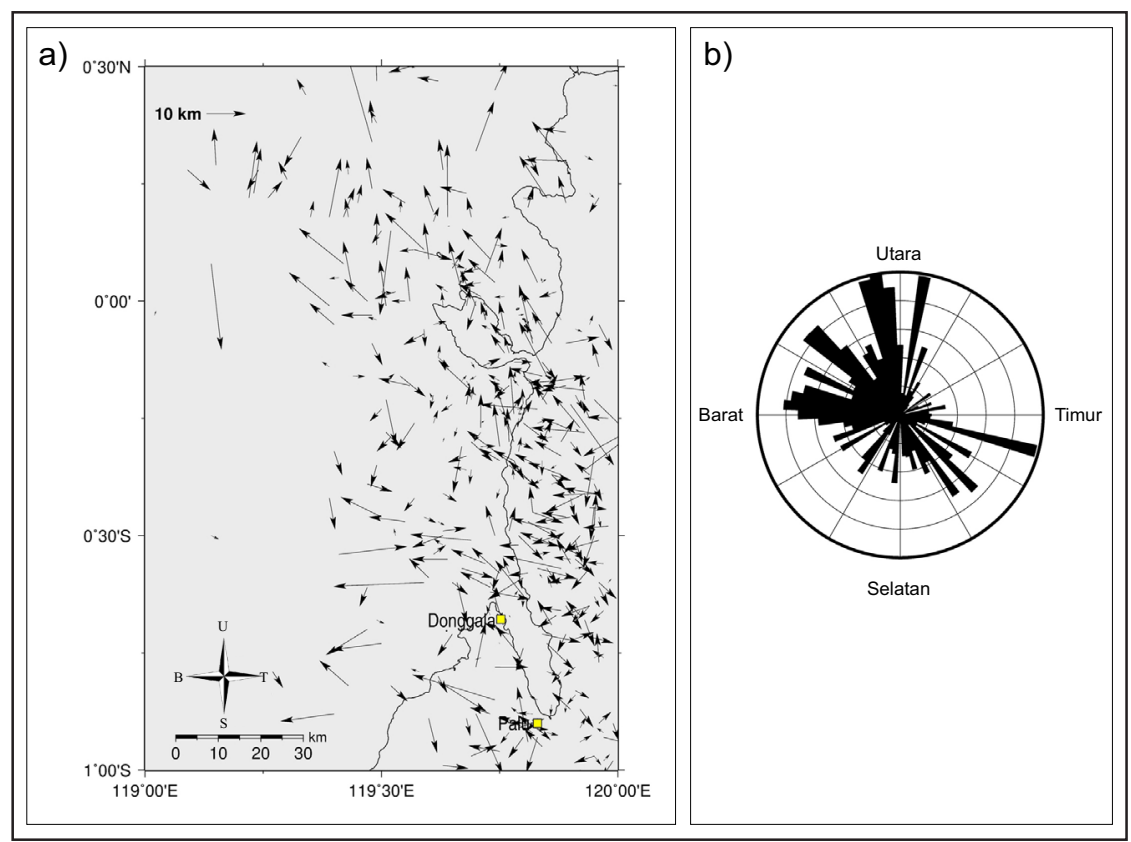

Gambar 2. a) Vektor perpindahan episenter gempa bumi dari sebelum ke sesudah relokasi hiposenter. b) Diagram mawar dari hasil relokasi hiposenter.

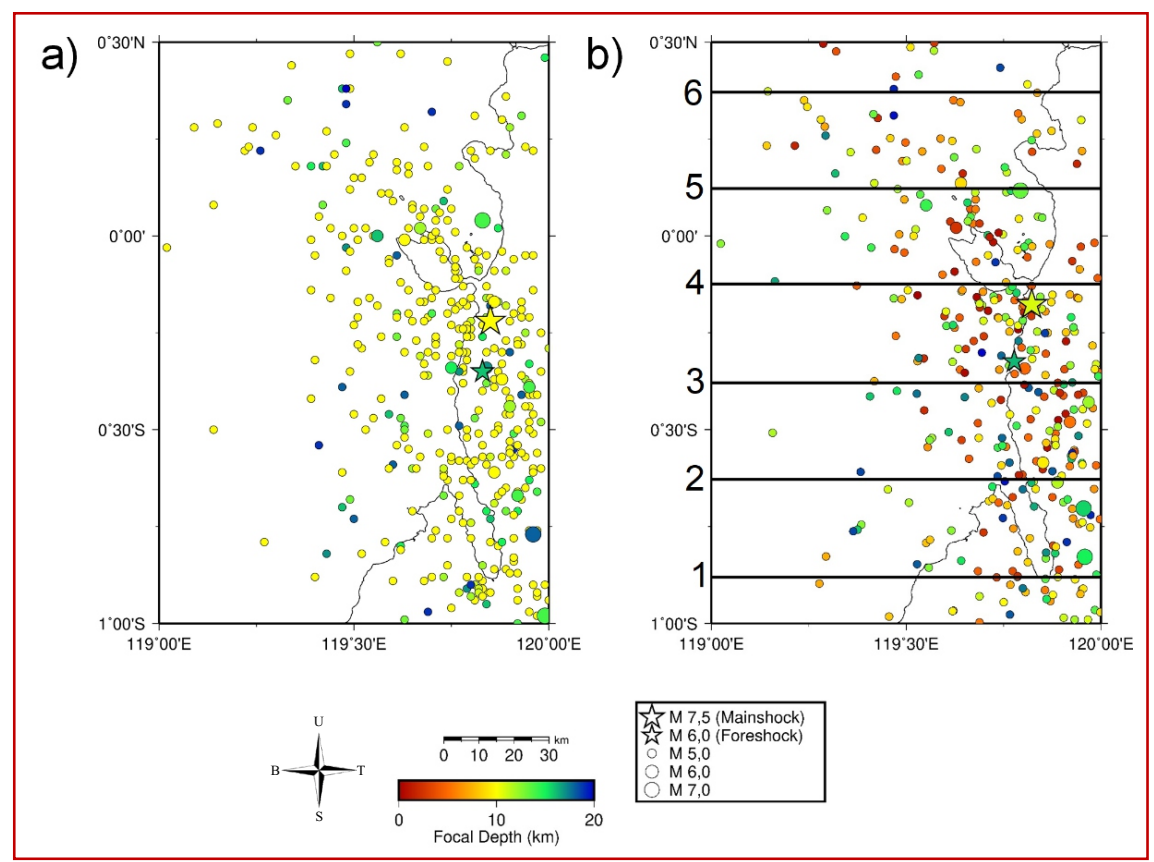

Gambar 3. Sebaran episenter gempa bumi sebelum (a) dan sesudah relokasi hiposenter (b). Garis 1-6 merupakan penampang vertikal arah barat-timur yang digunakan untuk merekontruksi Sesar Palu. Lebar penampang 1-6 sebesar 0,25 .

mana sebelum relokasi hiposenter mayoritas kedalaman berada pada kedalaman fix depth $10 \mathrm{~km}$ seperti ditunjukkan oleh Gambar 3(a). Deliniasi struktur sesar tidak bisa dilakukan jika sebaran kedalaman hampir homogen ( $f i x$ depth) sehingga relokasi hiposenter mutlak dilakukan untuk mendeliniasi suatu struktur sesar aktif. Adapun untuk informasi gempa bumi parameter hiposenter untuk keperluan tanggap darurat dikirim oleh BMKG dalam waktu kurang dari 5 menit dari waktu kejadian gempa bumi. 
Hasil relokasi hiposenter gempa bumi diplot dalam ruang dua dimensi sebagai penampang seismisitas pada arah barat-timur. Untuk menegaskan pola-pola kelurusan sebaran hiposenter, dilakukan pengelompokan (clustering) sebaran hiposenter dengan metode heat map (QGIS, 2013). Rekonstruksi bawah permukaan dari sistem Sesar Palu pada penelitian ini dilakukan melalui analisis pola kelurusan pada penampang vertikal. Analisis dilakukan pada daerah antara $119,0^{\circ}-120,0^{\circ}$ Bujur Timur dan antara $1,0^{\circ}$ LS$0,5^{\circ} \mathrm{LU}$. Area tersebut dibagi menjadi 6 sektor di mana sektor 1 dimulai dari selatan dan menerus ke utara untuk sektor-sektor berikutnya. Lebar setiap sektor adalah $0,25^{\circ}$. Bidang-bidang sesar pada penampang setiap sektor diberi nama dengan P untuk Sesar Palu utama, B untuk sesar di barat Sesar Palu dan T untuk sesar di timur Sesar Palu. Untuk bidang sesar yang merupakan cabang dari sesar B dan sesar T tersebut ditambahkan nomor di belakang abjad misalnya B1 untuk cabang pertama dari sesar B. Dari sesar-sesar yang teridentifikasi pada penampang vertikal
Gambar 4(a) dibuat rekonstruksinya pada peta Gambar 4(b) sehingga didapatkan gambaran umum sistem Sesar Palu.

Sektor 1 berada paling selatan pada posisi antara $0,75^{\circ}-1,0^{0}$ LS. Pada sektor ini terdapat sesar utama atau Sesar Palu (SP), sesar barat (B1) dan dan sesar timur (T1). Sesar B1 membatasi Lembah Palu di sisi barat dan sesar P membatasi Lembah Palu di sisi timur. Sesar SP dan B1 memiliki kemiringan ke arah timur. Sementara sesar T1 memiliki kemiringan ke arah barat. Penyesaran di ketiga bidang sesar dimulai dari kedalaman $5 \mathrm{~km}$ hingga $16 \mathrm{~km}$.

Sektor 2 yaitu wilayah antara $0,50^{\circ}-0,75^{\circ} \mathrm{LS}$ sesar P, B1 dan T1 masih menerus ke arah barat laut hingga masuk ke wilayah perairan. Kedalaman penyesaran antara $2 \mathrm{~km}$ hingga $13 \mathrm{~km}$. Pada sektor ini sesar T1 mengalami pelandaian sudut kemiringan dan memiliki percabangan yaitu sesar T2. Percabangan tersebut dimulai pada kedalaman $15 \mathrm{~km}$ dan menerus ke atas hingga kedalaman $4 \mathrm{~km}$. Pada sektor ini juga berkem-

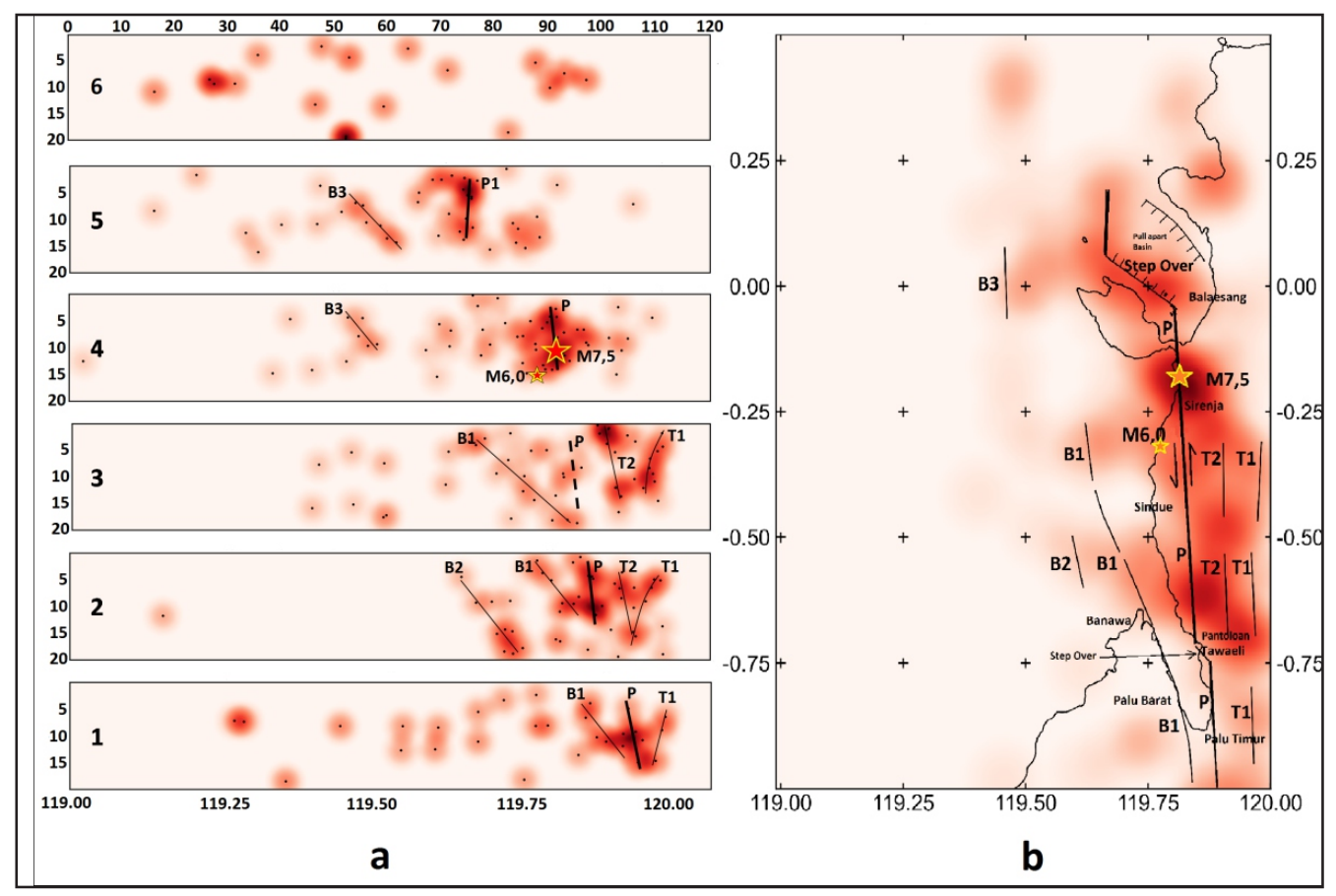

Gambar 4.a) Penampang melintang arah barat-timur dari setiap sektor. Zona merah adalah kluster seismisitas. Garis hitam adalah kelurusan kluster seismisitas yang diduga bidang sesar. Bintang besar adalah hiposenter gempa utama dan bintang kecil adalah hiposenter gempa pendahulu. b) Peta hasil rekonstruksi penampang pada gambar (a). Zona merah adalah kluster seismisitas. Garis hitam adalah rekonstruksi sesar-sesar di permukaan berdasarkan penampang pada gambar (a). Bintang besar adalah episenter gempa utama dan bintang kecil adalah episenter gempa pendahulu. 
bang sesar B2 pada jarak $20 \mathrm{~km}$ di sebelah barat sesar B1. Sesar B2 ini memiliki kemiringan ke arah timur sejajar dengan kemiringan sesar B1.

Sektor 3 antara $0,25^{\circ}-0,50^{\circ}$ LS sesar B1, T1 dan T2 masih menerus. Adapun sesar B2 sudah tidak ditemukan. Sesar P (garis putus-putus) seolah menghilang dengan tidak tampaknya seismisitas pada penampang. Tidak adanya seismisitas selama kurun 2009-2018 di daerah ini (seismic gap) ternyata menyimpan potensi gempa bumi besar. Berdasarkan analisis Empirical Green's Function, slip terbesar terjadi di sektor ini (Priyobudi dan Ramdhan, 2019). Hal ini membuktikan bahwa zona sepi gempa bumi di segmen Sesar Palu merupakan potensi bahaya yang besar. Gempa bumi pendahuluan (foreshock) dengan 6,0 Mw terjadi pada segmen ini.

Sektor 4 antara $0,00^{\circ}-0,25^{\circ} \mathrm{LS}$ sesar B1, T1 dan T2 sudah tidak nampak. Sementara itu sesar $\mathrm{P}$ masih menerus. Di sekitar sesar P terdapat zona seismisitas tinggi yang menunjukkan rumitnya sistem sesar di sekitar sesar P pada sektor ini. Zona seismisitas tinggi ini berada pada rentang kedalaman 3-15 km. Pada sektor inilah awal terjadinya gempa bumi utama $\mathrm{Mw}$ 7,5. Sekitar $40 \mathrm{~km}$ di barat zona sesar P terdapat sesar B3 dengan kemiringan ke arah timur.

Sektor 5 antara $0,00^{\circ}-0,25^{\circ} \mathrm{LU}$ jejak dari sesar $\mathrm{P}$ sudah tidak ditemukan, tetapi $15 \mathrm{~km}$ di baratnya terdapat zona seismisitas tinggi. Zona ini diduga merupakan bagian dari Sesar Palu yang step over ke arah barat. Untuk itu zona tersebut dinamakan sesar P1. Pada sektor ini berkembang juga sesar B3 sebagai terusan dari sektor 4. Zona ini diduga merupakan zona bukaan (transtensional) dari sistem Sesar Palu yang membentuk pull-apart basin sehingga membentuk Teluk Balaesang. Gambar 5 menunjukkan model sistem sesar mendatar dengan zona bukaannya (Blès and Feuga, 1986). Model sistem sesar tersebut mendekati kondisi yang terjadi dalam sistem sesar Palu di sekitar Teluk Balaesang.

Sektor 6 antara $0,25^{\circ}-0,50^{\circ} \mathrm{LU}$ tidak ditemukan zona seismisitas dengan orientasi tertentu. Zona seismisitas pada sektor ini cenderung menye-

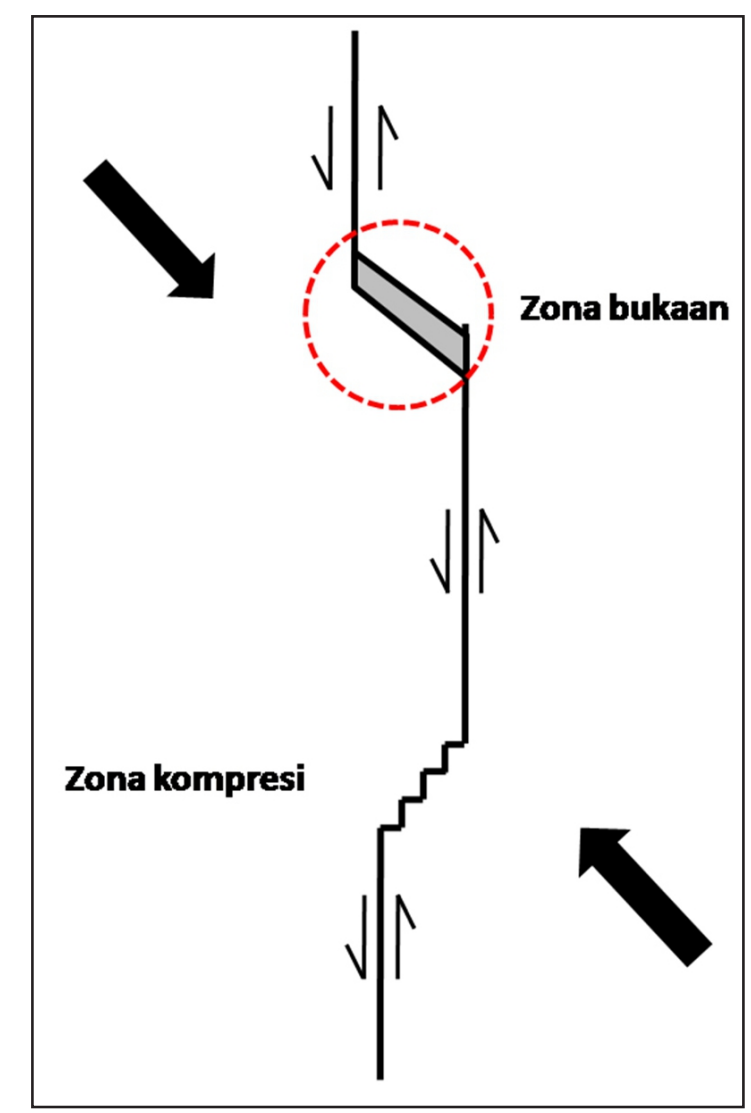

Gambar 5. Model sistem sesar mendatar dengan zona bukaannya (Blès dan Feuga, 1986)

bar tidak beraturan. Dapat disimpulkan bahwa sistem Sesar Palu di utara hanya sampai sektor 5 .

Hasil rekontruksi dari Gambar 4(a) yang menjadi 4(b) menunjukkan sesar B yang terdapat di sisi timur lembah Palu merupakan sesar utama dari sistem Sesar Palu. Sesar P merupakan bidang lurus berarah utara-selatan membentang dari $0^{\circ}$ (Balaesang) hingga $1^{0} \mathrm{LS}$ (Palu Timur). Proses penyesaran di sepanjang bidang sesar utama ini dimulai dari hiposenter di sekitar Sirenja pada kedalaman $11 \mathrm{~km}$, lalu merambat ke selatan menuju Kota Palu dengan kedalaman yang semakin dangkal. Berakhirnya bidang sesar utama di sektor 4 (sekitar $0^{0} \mathrm{LS}$ ) diakibatkan oleh adanya step over ke arah barat. Hal ini dapat menjelaskan mengapa proses slip tidak merambat ke utara pada peristiwa gempa bumi tersebut. Perambatan slip yang semakin dangkal ke selatan didukung oleh keberadaan bidang sesar utama yang berkembang dari kedalaman $16 \mathrm{~km}$ hingga kedalaman $3 \mathrm{~km}$ di sekitar Kota 
Palu. Hal ini sesuai dengan hasil analisis data GPS bahwa locking depth sesar Palu adalah antara 8-16 km (Walpersdorf drr., 1998).

Sesar B1 terletak di sisi barat lembah Palu. Sesar ini berarah barat laut-tenggara berupa bidang lengkung. Berdasarkan model sesar Riedel (Riedel, 1929), sesar B1 merupakan sesar sintetik dari sesar utama P, lihat Gambar 4(a). Sesar sintetik lainnya adalah Sesar B2 dan B3, tetapi kedua sesar tersebut tidak berkembang dengan baik. Lengkungan sesar B1 membentuk pola sigmoid. Sesar sinistral Yapen memiliki pola sigmoid yang mirip dengan sesar Palu yang dinamakan sebagai rhomboidal pull apart basin (Watkinson dan Hall, 2017). Jika mengacu pada model Riedel (Riedel, 1929) maka Teluk Palu hingga perairan di sebelah barat Donggala terbentuk oleh mekanisme tarikan (pull apart). Mekanisme tarikan ini menyebabkan berkembangnya sesar-sesar normal atau longsoran yang dapat memicu terjadinya tsunami. Adanya step over kecil di sekitar Pantoloan (antara sektor 1 dan sektor 2) diduga merupakan penyebab longsornya massa batuan pada dinding teluk Palu hingga menyebabkan tsunami pada peristiwa gempa bumi 28 September 2018.

\section{KESIMPULAN}

Struktur sesar di bawah Kota Palu dan sekitarnya berhasil direkonstruksi dari sebaran hiposenter yang terelokasi dari katalog gempa bumi BMKG. Sesar Palu terdiri dari sesar utama berarah utara-selatan yang membentang mulai dari perbatasan Sirenja-Balaesang hingga Palu Timur sepanjang kurang lebih $80 \mathrm{~km}$. Kedalaman penyesaran berkisar antara $3-16 \mathrm{~km}$. Selain sesar utama ada juga sesar barat yang merupakan sesar sintetik dari Sesar Palu dan sesar timur. Penampang vertikal menunjukkan hubungan antara sesar utama (P), sesar barat (B1) dan sesar timur (T1 dan T2) adalah cabang yang membentuk struktur bunga (flower structure). Sesar Palu mengalami step over di sekitar Balaesang (utara) dan Pantoloan (selatan). Adanya step over di utara menyebabkan berhentinya perambatan slip ke utara sehingga slip merambat ke selatan. Adanya step over di sekitar Pantoloan diduga menjadi penyebab runtuhnya dinding batuan di Teluk Palu yang memicu tsunami.

\section{UCAPAN TERIMA KASIH}

Ucapan terima kasih yang tidak terkira disampaikan kepada BMKG yang telah memberikan akses katalog gempa bumi sehingga bisa digunakan pada penelitian ini. Umumnya gambar pada penelitian ini diplot menggunakan program open source GMT dan QGIS.

\section{PUSTAKA}

Bao, H., Ampuero, J.P., Meng, L., Fielding, E. J., Liang, C., Milliner, C. W., Feng, T., dan Huang, H., 2019. Early and persistent supershear rupture of the 2018 magnitude 7.5 Palu earthquake. Nature Geoscience, 12 (3), hal. 200-205.

Bellier, O., Sébrier, M., Beaudouin, T., Villeneuve, M., Braucher, R., Bourlès, D., Siame, L., Putranto, E., dan Pratomo, I., 2001. High slip rate for a low seismicity along the Palu-Koro active fault in central Sulawesi (Indonesia), Terra Nova, 13(6), hal. 463-470. DOI: 10.1046/j.13653121.2001.00382.x.

Blès, J.-L., dan Feuga, B., 1986. The fracture of rocks.

Fang, J., Xu, C., Wen, Y., Wang, S., Xu, G., Zhao, Y., dan Yi, L., 2019. The 2018 Mw 7.5 Palu Earthquake: A Supershear Rupture Event Constrained by InSAR and Broadband Regional Seismograms, Remote Sensing, 11(11), 1330.

Grandis, H., 2009. Pengantar pemodelan inversi geofisika, Bandung: Himpunan Ahli Geofisika Indonesia.

Hamilton, W. B., 1979. Tectonics of the Indonesian region, US Govt. Print. Off.

Ismullah, M. M. F., Nugraha, A. D., Ramdhan, M., dan Wandono, 2017. Precise Hypocenter Determination around Palu Koro 
Fault: a Preliminary Results, IOP Conference Series: Earth and Environmental Science, 62, 012056. DOI: 10.1088/17551315/62/1/012056.

Jamidun, J., Rusydi, M., Kirbani, S., Subagio, P., dan Suryanto, W., 2019. Analisis dan Model Inversi Gaya Berat 2D untuk Penampakan Sesar Palu Koro Di Sulawesi Tengah Indonesia, Natural Science: Journal of Science and Technology, 8 (1).

Kennett, B. L. N., Engdahl, E. R., dan Buland, R., 1995. Constraints on seismic velocities in the Earth from traveltimes, Geophysical Journal International, 122(1), hal. 108-124. DOI: 10.1111/j.1365246X.1995.tb03540.x.

Nugraha, A. D., Shiddiqi, H. A., Widiyantoro, S., Thurber, C. H., Pesicek, J. D., Zhang, H., Wiyono, S. H., Ramdhan, M., Wandono, dan Irsyam, M., 2018. Hypocenter Relocation along the Sunda Arc in Indonesia, Using a 3D Seismic Velocity Model, Seismological Research Letters, 89 (2A), hal. 603-612. DOI: $10.1785 / 0220170107$.

Pesicek, J., Thurber, C., Zhang, H., DeShon, H., Engdahl, E., dan Widiyantoro, S., 2010. Teleseismic double-difference relocation of earthquakes along the Sumatra-Andaman subduction zone using a 3-D model, Journal of Geophysical Research: Solid Earth, 115 (B10).

Priyobudi, dan Ramdhan, M., 2019. Supershear rupture of the 28 September 2018 Palu earthquake inferred from Empirical Green's Function analysis, Journal of Physics: Conference Series, 1341, 082011. DOI: 10.1088/17426596/1341/8/082011.

QGIS, 2013. QGIS: A Free and Open Source Geographic Information System.

Ramdhan, M., dan Priyobudi, 2019. Hypocenter relocation analysis of $7.5 \mathrm{Mw}$ Palu and its aftershocks: A preliminary result, Journal of Physics: Conference Series,
1341, 082009. DOI: 10.1088/17426596/1341/8/082009.

Ramdhan, M., Priyobudi, Triyono, R., Daryono, Heryandoko, N., dan Imananta, R. T., 2019. Seismicity around Sunda strait and its surroundings based on hypocenter relocation using 3-D velocity: a preliminary result of relocated hypocenter database construction from the BMKG catalog, Journal of Physics: Conference Series, 1341, 082010. DOI: 10.1088/17426596/1341/8/082010

Ramdhan, M., dan Nugraha, A. D., 2013. Study of seismicity around Toba area based on relocation hypocenter result from BMKG catalogue, Padjadjaran International Physics Symposium 2013 (PIPS-2013): Contribution of Physics on Environmental and Energy Conservations, AIP Publishing, 1554, 242-244.

Ramdhan, M., Widiyantoro, S., Nugraha, A. D., Métaxian, J.-P., Saepuloh, A., Kristyawan, S., Sembiring, A. S., Santoso, A. B., Laurin, A., dan Fahmi, A. A., 2017. Relocation of hypocenters from DOMERAPI and BMKG networks: a preliminary result from DOMERAPI project, Earthquake Science, 30 (2), hal. 67-79.

Riedel, W., 1929. Zur Mechanik geologischer Brucherscheinungen ein Beitrag zum Problem der Fiederspatten., Zentbl. Miner. Geol. Palaont. Abt., hal. 354-368.

Socquet, A., Simons, W., Vigny, C., McCaffrey, R., Subarya, C., Sarsito, D., Ambrosius, B., dan Spakman, W., 2006. Microblock rotations and fault coupling in SE Asia triple junction (Sulawesi, Indonesia) from GPS and earthquake slip vector data, Journal of Geophysical Research: Solid Earth, 111 (B8). DOI: 10.1029/2005JB003963

Walpersdorf, A., Vigny, C., Manurung, P., Subarya, C., dan Sutisna, S., 1998. Determining the Sula block kinematics in the triple junction area in Indonesia by GPS, Geophysical Journal International, 135(2), 
hal. 351-361. DOI: 10.1046/j.1365246X.1998.00641.x.

Watkinson, I. M, dan Hall, R., 2017. Fault systems of the eastern Indonesian triple junction: evaluation of Quaternary activity and implications for seismic hazards, Geological Society, London, Special Publications, 441 (1), hal. 71-120.

Wessel, P, dan Smith, W. H., 1998. New, improved version of Generic Mapping Tools released, Eos, Transactions American Geophysical Union, 79(47), hal. 579-579.

Widiyantoro, S., dan van der Hilst, R., 1996. Structure and Evolution of Lithospheric
Slab Beneath the Sunda Arc, Indonesia. Science, 271 (5255), hal. 1566-1570. DOI: $10.1126 /$ science. 271.5255 .1566

Widiyantoro, S., dan van der Hilst, R., 1997. Mantle structure beneath Indonesia inferred from high-resolution tomographic imaging, Geophysical Journal International, 130 (1), hal. 167-182. DOI: 10.1111/j.1365-246X.1997.tb00996.x

Zhao, B., Shi, Y., dan Gao, Y., 2011. Relocation of aftershocks of the Wenchuan Ms 8.0 earthquake and its implication to seismotectonics. Earthquake Science, 24 (1), hal. 107-113. 